\title{
THE EFFORT OF WEST SUMATRA PROVINCE TO EMBRACE HALAL TOURISM
}

\author{
Arinaldo Habib Pratama,S.IP, Sulistiyanto,S.E,M.M.,M.Sc.,P.S.C, Dr. Yusuf Ali,S.E,M.M \\ Faculty of Defense Management, Indonesia Defense University \\ arinaldopratama@gmail.com
}

\begin{abstract}
In order to embrace economic resilience as form of national resilience, tourism effort is needed so every provinces in Indonesia able to introduce any potential that they have globally. Halal tourism is one way to gaining lucrative prospect from muslim tourist, since muslim travellers are spending USD 220 billion annually. For the start, at 2012, Indonesia's Ministry of Tourism introduced 12 provinces as halal tourism destinations and adopt some regulations to facilitate the implementation and activation of halal tourism, including West Sumatra. Halal tourism in West Sumatra already got recognition in form of achievements, such as The World Halal Tourism Award 2016 and Anugerah Wisata Halal Nasional 2016 from Indonesia's Ministry of Tourism. This study will explain how West Sumatra able to develop themselves as one of halal tourism destination in Indonesia. Concepts that will be used in this study are public policy and branding strategy. The research conducted with qualitative research. The result of this research is through public policy and branding in tourism effort, West Sumatra succesfully convince the tourist that the province is friendly toward muslim tourist through various rules and incentive toward shareholder that responsible to promote halal tourism effort. Also, as province that mostly populated by muslim, West Sumatra's branding effort succesfully show that religion and culture able to go along together.
\end{abstract}

Keyword: Halal Tourism, West Sumatra, Public Policy, Branding

\section{Introduction}

Halal tourism is already started to become one of most studied subject in regard of tourism as one of academic subject, since halal tourism has many prospect that could be discovered by country that have muslim-majority as their population and got many interesting places that could be designated as tourist spot. In practical term, halal tourism is synonymous with religion tourism.

There are different reason of why people choose conducted religion tourism. The first reason, according to Sigaux and Vukanic, is the opportunity for people to recognize and develop their spiritual needs, but also tourism, as a specific use such as leisure time, has come to be viewed by some as an act of spiritual or sacred journey. Meanwhile, Smith said that the reason of why people conducted religion tourism is a search for something. On the one hand, there is the extreme form of which is the holy pilgrimage, a journey driven by faith, religion, and spiritual fulfillment; while on the other hand, there are tourists who may seek to satisfy personal interests or spiritual needs through tourism. On two sides of this can be found differences in shape or intensity of religious tourism which is motivated by a greater degree or less with religion or, conversely, needs-based culture or knowledge. Another definition from this activity, according to Cohen, is those who come to observe, but who will also time to time take part in worship. Pilgrims are those who are worshiping the gods/God at the site whereas tourists simply spectators who remain uninvolved. 
As part of religion tourism, halal tourism take three major aspect that differentiate this kind of tourism from other. Those aspect are culture, location, product and service, and purpose of the trip. According to Henderson, Halal tourism can't be separated with Islamic teachings regarding behaviourisms, dress, conduct and diet. On the other hand, it is claimed that Islamic tourism attracts many travellers entirely interested in what is termed 'Islamic culture'. It's clearly can be seen that Muslim customer is strict regarding to product and service that can be classified into which products are Sharia compliant and which products are not Sharia compliant. The emergence of halal tourism could be seen in various indicator such as existence of halal food, qibla' (direction plate that show which show the pointer to Mecca) in hotel room, and certification of muslim friendly hotel.

Halal tourism itself, as a trend, keep showing rising number and bigger prospect than before. For example, at 2015, according to research from Tripfez, muslim tourist spent around US\$ 145 billion. United States of America (USA) and European Union (EU) represent represent $44 \%$ of the global Muslim travel market. Muslim tourist from Saudi Arabia, according report from Organisation of Islamic Countries (OIC), become biggest contributor in muslim countries spending's trend, with \$US 17.8 billion. The conclusion that can be conducted from this data is muslim tourist are ready spent their money in country or place (hotel,tourism object,etc) that accomodate their Islamic belief, although the country is not populated by muslim-majority population.

Indonesia is one of many countries that already announce their availability to accomodate muslim tourist with halal tourism. In general, Indonesia has a Indonesia has a lot of potential in the form of a beautiful natural landscape with 17,100 islands and 742 languages. In addition, the Indonesian population of 250 million people is the largest archipelago with a length of $5,120 \mathrm{~km}$ from west to east and 1,760 km from north to south. In shariah tourism needed some major aspects, namely the availability of halal food, prayer facilities were adequate, service iftar during Ramadan, as well as the restrictions on activities that are not in accordance with shariah. Also, to ensure the success of halal tourism, Indonesia's Ministry Tourism already elaborate policy that will implementing and supervise the sustainability from halal tourism program. Those policy are cooperating with National Cleric Council (Majelis Ulama Indonesia/ MUI) to formulate regulation that needed to supervise the availability of facilities that accomodate muslim tourist need and designating province that having local value that compatible with halal tourism, so the ministry, together with the local government, will develop promotion and tourism infrastructure that suitable with halal tourism. MUI support Indonesia's Ministry of Tourism in establishing various regulation, such as the Regulation of the Minister of Tourism and Creative Economy No. 2/2014 on Guidelines for Implementation of Shariah Hotel Business. In the latter policy, Indonesia's Ministry of Tourism already deciding 3 provinces that will be project example of halal tourism. Those provinces are West Nusa Tenggara (Nusa Tenggara Barat), Nangroe Aceh Darussalam, and West Sumatra (West Sumatra). 
Global recognition for West Sumatra in halal tourism comes when the local government of West Sumatra receiving award in World Halal Tourism Award 2016 in Abu Dhabi. West Sumatra's local government received award consist of Best Halal Tourism Destination, Best Coulinary, Best Halal Restaurant, and Best Travel Agent. At first, West Sumatra are capable to conduct various international event, such as bicycle race Tour de Singkarak, paragliding event Fly for Fun in Maninjau Lake, and surf competition called International Pro Surf Competition which conducted in Mentawai. With the international recognition and the local government will to adjust tourism activity with adat basandi syarak, syarak basandi kitabullah, which means Minangkabau custom and Islamic belief are not separated, the local government their effort to promote halal tourism through 331 hotel and various tourism object that can be found in this province.

The research will discuss about West Sumatra local government policy to boost halal tourism from 2014, which become the year of firstly launched Grand Plan of West Sumatra's Tourism Development Plan 2014-2025, until 2018. The concept that would be used in this journal are public policy and branding. The public concept will be used, so the reader will understand how local government will push halal tourism so the policy will be benefit many people through foreign currency by muslim tourist. The branding strategy concept will be used, so the reader will understand how West Sumatra's halal tourism perceive itself toward their soon-to-be consumer.

Thoha (2012) define public policy as :

- Public policy is social practice, not an isolated event. Therefore, public policy si something that created by government, which formulated by every event that happened in society. Those event grown inside and not an isolated event that separated from society.

- Public Policy is response from event that already happened, both for creating harmony from conflicted side, or creating incentives for common action to deflect any harmful effect for every parties.

The implementation of public policy should be consist of :

- Specification and details of program, that is how and where related body and institution should implement their action

- Resource allocation, that is how the fund distributed, what kind of personel that needed to ensure that the program will be succeed, and organisation that will complete every task,

- Decision, that is how the decision would be implemented

Branding strategy is deciding element that going to be put together so a product will be having lot of distinctive feature, according to Schultz and Barnes (1999). Brand strategies consist of :

- Brand positioning. The definition of brand positioning is how a entity show the differentiation between their product and other product.

- Brand identity. The definition of brand identity is how the identity forming itself, including the background. 
- Brand personality. The definition of brand personality is how to improve pulling factor from a brand.

\section{Research Method}

The research would be conducted by qualitative method. According to Cresswell (2008), the definition of qualitative method is an approach that used to explore and understanding an event. To understand certain event, the researcher will reading various literatur or interviewing various sources that usually holding responsibility or taking role inside certain phenomena or event that become research object.

From data that already gathered from various sources, which usually in written words or voice records, intepretation could be deduced. The most important factor from qualitative research is reearch results are affected by interview result that given by the sources, so the prejudice that come from theory or researcah should be put aside.

The data gathering of this research would be conducted by literature review. Literature reviews is understanding and learning written literatures that could be in form of book, journal, which discuss topic that become the centre of the research. From the learning, understanding, and interpretation process, the ideas, opinion, or critic toward the topic could be arranged to be understandable narrative for everyone.

\section{Findings And Argument}

\subsection{Implementation of Public Policy in Support of Halal Tourism in West Sumatra}

The development of halal tourism in West Sumatra is suitable with what local government of West Sumatra and local parliament of West Sumatra already agreed in Grand Plan of West Sumatra's Tourism Development Plan 2014-2025. Halal tourism is compatible with article 58 of Grand Plan of West Sumatra's Tourism Development Plan 2014-2025. In this article, the strategies of tourism research and development including market research and development of new market in tourism.

In order to introduce halal tourism concept in West Sumatra, the first step that had to be done in socialisation to tourism entrepreneur in the province. According to Riza Chandra, Promotion Staff in Marketing Sector, Tourism Agency of West Sumatra's Local Government, the local government need five kind of expert to socialise the ideal of halal tourism that come from national standard (Ministry of Tourism) and international standard (Organisation of Islamic Cooperation). Those expert should be come from government, academics, tourism entrepreneur, journalist and local actor. Socialisation as a program should conducted so every actor able to understand every international and certification that has to be fulfilled to undergo proper halal tourism. In socialisation, local tourism agency of West Sumatra's local government usually asking local tourism entrepreneur to taking care of food safety, especially halal food, and availabiliy of praying room, while strengthening synergy with local government 
agency and Local Cleric Assembly (Majelis Ulama Indonesia) for various matter, such as food safety and restriction of entertainment that banned by Islamic practice. This effort is conducted so halal tourism could be supported by every stakeholder.

The second step that used to promote halal tourism in West Sumatra is certification. West Sumatra's local government, together with Local Cleric Assembly, always motivate local entrepreneur in accomodation and food to taking care of halal certification. For example, Buya Gusizal, head of West Sumatra's Local Cleric Assembly, motivate hotel entrepreneur to change their hotel status into sharia hotel. The most distinctive feature from sharia hotel are praying room, no night entertainment inside it, and every couple that entering hotel should show their marriage registration. But, local entrepreneur in West Sumatra have their own challenge in taking care of those certification. Those challenges are the halal certification can't be handled through online and lack of willingness from local entrepreneur to prove their hygiene condition from their food and hotel. One of incentive that provided by government so the local entrepreneur want to renew their certification is local government support to implement Article 44, law no. 33 years 2014, about Guarantee of Halal Product. The law said that the payment of halal certification administration could be done by third party. The West Sumatra's local government should become sponsor as third party, ofcourse after doing selection and inspection of the selected local entrepreneur .

The third step in promote halal tourism in West Sumatra is incoorporation of local value inside halal tourism. According to Article 2 of Grand Plan of West Sumatra's Tourism Development Plan 2014-2025 the development of tourism should be directed into development based on culture, religion and environment. This means the effort of local government both of boost authentic culture that come from West Sumatra and embracing Islamic value and practice. In practice, local government will ask local tourism agency to only guide tourist into restaurant that already get their halal certificate, as proof of hygienity, and also restaurant that put local cuisine as their prioritised menu. Another practice of synergy between religion and culture based on adat basandi syarak, syarak basandi kitabullah is desa halal. Desa halal means a village could consist of people and places that incoorporated with Islamic and local value. From literature that researcher already read, local government already guide two village as their desa halal, which is Pilubang Village in Payakumbuh and Pariangan Village in Tanah Datar. Pilubang Village with Tourism Agency of West Sumatra's government, after 2014, decide to suggesting some Islamic value to various accomodation place with branding "Pilubang Resort Syariah" in order to repress adultery and disorder act like LGBT, so both of local society and tourism able to have healthy relationship without conflict. The second, Pariangan Village, has various mosque with arsitecure from Dongson, Tibet.

The final step that will be explained in this paper about local government efforts to promote halal tourism in West Sumatra is aboard promotion through investment forum.In national spectrum, government support into economic 
development in West Sumatera's tourism sector fromed through Regional Investment Forum 2017 that established by West Sumatra's local government cooperation with Investment Coordinating Board (Badan Koordinasi Penanaman Modal), taking place from 15-17 October 2017. This forum also promoting various interesting tourism object in West Sumatra to national and international investor. The numbers of investor that invited to this forum are 300 investor. West Sumatra's local government also doing what could be called as jemput bola or being proactive promoting local tourism in various countries. Most of the time, West Sumatra's governor, Irwan Prayitno, led the local government delegation to various countries. At May 2017, the governor promoting Mandeh tourism area to Dutch entrepreneur in Indonesia's Embassy in Den Haag, Netherland, through forum called Business and Investment Forum (Forum Bisnis dan Pariwisata). At April 2018, the governor promoting Mandeh to USA businessman in Chicago, through forum called "Business Opportunities in West Sumatera". At July 2018, Mandeh also being promoted in Marocco through forum called "MaroccoIndonesia Business Forum". For the information, Mandeh tourism area which located in Pesisir Selatan, West Sumatra expand their road access through 42,48 km road building that using state fund as many as Rp 77.74 billion and also being built sharia based hotel in the area.

\subsection{Implementation of Branding in Support of Halal Tourism in West Sumatra}

As explained before, Adat Basandi Syarak, Syarak Basandi Kitabullah that exist in West Sumatra is suitable with The Halal Wonders spirit that brought by Indonesia's Tourism of Minister. The spirit is joint implementation between local value and Islamic belief and practice. In practice, a tourist that come to West Sumatra able to enjoy not only hospitality and conformity with Islamic belief, but also nature scenery that could be seen in various event like Tour de Singkarak and Mentawai Pro Surf Competition.

The difference between halal tourism in West Sumatra and other place is the province has different culture and norm. As a multicultural country, Indonesia has many culture potential to be found, and also has economic added value.

Halal Tourism in West Sumatra supported by islamic based culture. For example, West Sumatra's local government funding Center of Minangkabau's Culture Documentation and Information (Pusat Dokumentasi dan Informasi Kebudayaan Minangkabau). From there people could learnt about Minangkabau culture that based of islamic culture such as rabano which is instrumental show with lyric that telling about Prophet Muhammad's life story and salawat dulang which is about a group of male will beat the talam or drum while telling poem about Islamic value.

To strengthening West Sumatra culture identities, advertisement is needed so people will know about distinction between West Sumatra and other province. The effort to show West Sumatra's identities consist of booklet, using electronic media like television, and conductiong various cultural event. 


\section{Conclusion}

West Sumatra's halal tourism supported by two factor, natural scenery and fused culture between Minangkabau and Islamic value. West Sumatra's local government already support in effort of certification, but West Sumatra's local government hasn't initiated support for local tour agency to push cultural based route, so the tourist will able to visit tourism object that filled by diverse culture that embedded by Islamic value. So, people perception about halal tourism about halal tourism is not just about not being provided by food and entertainment that not permissible by Islamic belief, but to understand that culture and Islamic able to go along together.

Recomendation that could be given to West Sumatra's local government is to ask their understanding for not only fulfilling accomodation that suitable to Islamic practice, but also promote any local culture that related to Islam, so people could understand why adat basandi syarak, syarak basandi kitabullah exist.

\section{References}

Book

Creswell, J. W. (2008). Educational research: Planning, conducting, and evaluating quantitative and qualitative research (3rd ed.). Upper Saddle River, NJ: Pearson Education, Inc

E. Schultz(1999), Strategic Brand Communication Campaigns, University of Michigan

Fischer, F., Miller, G. J., \& Sidney, M. S. (2007). Handbook of Public Policy Analysis Theory, Politics, and Methods. New York: CRC Press Taylor \& Francis Group.

Gilbert Sigaux,Joan Eveline Mabel White (1966), History of Tourism,London, Leisure Arts and Boris Vukonic (1996), Tourism and Religion, Oxford, Pergamon

Jann, W., \& Wegrich, K. (2007). Theories of the Policy Cycle. In F. Fischer, G. J. Miller, $\& \mathrm{M}$.

Organisation of Islamic Cooperation (2017), Strategic Roadmap for Development of Islamic Tourism in OIC Member Countries, Ankara, Turkey

Smith, V. (1989), Hosts and Guests: The Anthropology of Tourism. Philadelphia, University of Pennsylvania Press

Salam Standard (2016), Global Economic Impact of Muslim Tourism, Tripfez, Kuala Lumpur

Thoha, M. (2012). Dimensi-dimensi Prima Ilmu Administrasi Negara. Jakarta: Raja Grafindo 
Supardi, M.d, (2006). Metodologi Penelitian. Mataram : Yayasan Cerdas Press.

\section{Journal}

Aan Jaelani (2017), Halal Tourism Industry in Indonesia: Potential and Prospects, International Review of Management and Marketing

Henderson, J. C. (2009). Islamic tourism reviewed. Tourism Recreation Research, 34(2), 207-211

Mila Falma Masful (2017), Pariwisata Syariah : Suatu Konsep Kepercayaan dan Nilai Budaya Lokal di Daerah Pedalaman Pilubang, Payakumbuh, Sumatera Barat, Jurnal The Messenger, Universitas Semarang

Mohamed Anwar Omar and Zulayti Zakaria (2010), Kesenian Bernuansa Islam Suku Melayu Minangkabau, Jurnal Melayu, Universiti Kebangsaan Malaysia

\section{Newspaper Article}

Asdhiana, I.M. (2013), Indonesia Potential to Develop Tourism Sharia. Available from: http://www.travel.kompas.com/ read/2013/10/31/0852207/. (in Indonesian)

Dadan M. Ramdan, Masih banyak UKM yang belum kantongi sertifikasi halal, Jakarta, Kontan , publisehd in 30 September 2018, https://peluangusaha.kontan.co.id/news/masih-banyak-ukm-yang-belumkantongi-sertifikasi-halal

Gina Yustika Dimara, Berkenalan dengan Nagari Pariangan, 'Desa Terindah di Dunia, kumparan, Jakarta, published in 13 Januari 2018, https://kumparan.com/@kumparantravel/berkenalan-dengan-nagari-pariangandesa-terindah-di-dunia

Indonesia's Ministry of Foreign Affairs, Sumatera Barat Promosikan Peluang Investasi dan Bisnis di Belanda, published in 25 May 2017, https://www.kemlu.go.id/thehague/id/berita-agenda/beritaperwakilan/Pages/Sumatera-Barat-Promosikan-Peluang-Investasi-dan-Bisnis-diBelanda.aspx

Indonesia's Ministry of Public Work, Tahun 2018 Kementerian PUPR Alokasikan Rp 127,38 Miliar untuk Lanjutan Pembangunan Jalan Wisata Mandeh, published in 22 June 2018, https://www.pu.go.id/berita/view/15823/tahun-2018-kementerian-pupralokasikan-rp-127-83-miliar-untuk-lanjutan-pembangunan-jalan-wisata-mandeh 
Info Sumbar, Sumbar Dinobatkan Sebagai Wisata Halal Terbaik Dunia 2016, https://www.infosumbar.net/wisata/sumbar dinobatkan-sebagai-wisata-halalterbaik-dunia-2016/, dimuat pada tanggal 7 Desember 2016

Mi'raj News Agency, Buya Gusrizal : MUI Terus Mengupayakan Pemerataan Sertifikasi Halal di Sumbar, published in 20 July 2018, https://minanews.net/buya-gusrizalmui-terus-mengupayakan-pemerataan-sertifikasi-halal-di-sumbar/

Miko Elfisha, Sumbar Siap Bersaing di Regional Investment Forum 2017, Antara, published in 14 October 2017, https:/ / sumbar.antaranews.com/berita/214001/sumbarsiap-bersaing-di-regional-investment-forum-2017

Retno Wulandhari, Dinas Pariwisata Dorong Wisata Halal Sumbar Penuhi Standar Internasional, published in Monday, December 26, 2016, https://www.republika.co.id/berita/ekonomi/syariahekonomi/16/12/26/oisgz9374-dinas-pariwisata-dorong-wisata-halal-sumbarpenuhi-standar-internasional

Sapto Andika Chandra, Gubernur Sumbar Kembali 'Berdagang' Ke Luar Negeri, Republika, Published in Tuesday, 10 April 2018, https:/ / www.republika.co.id/berita/nasional/daerah/18/04/10/p6z4j3335gubernur-sumbar-kembali-berdagang-ke-luar-negeri

Singgalang, Ke Maroko, Gubernur Tawarkan Peluang Investasi Lagi, published in 29 June 2018, https:/ / hariansinggalang.co.id/ke-maroko-gubernur-tawarkan-peluanginvestasi-lagi/

\section{Law and Rules}

Peraturan Menteri Pariwisata dan Ekonomi Kreatif No. 02 Tahun 2014

Local Regulation of West Sumatra's Province, no.3 year 2014, about Grand Plan of West Sumatra's Tourism Development Plan 20142025,www.jdih.setjen.kemendagri.go.id/files/P_SUMBAR_3_2014.doc

\section{Interview}

Interview with Riza Chandra in Abdul Aziz (2018), Komunikasi Pemasaran Destinasi Wisata Halal oleh Dinas Pariwisata Provinsi Sumatera Barat dan Dinas Pariwisata Pemuda dan Olahraga Kabupaten Tanah Datar, Yogyakarta, Universitas Islam Indonesia. 